\title{
LĖTINĖ OBSTRUKCINĖ PLAUČIŲ LIGA (LOPL): RIZIKOS VEIKSNIAI
}

\author{
Aistė Naujokaitytė \\ Vilniaus universiteto Medicinos fakultetas
}

Raktažodžiai: lètinè obstrukcinè plaučių liga, LOPL, rizikos veiksniai.

\begin{abstract}
Santrauka
Lètinė obstrukcinè plaučių liga (LOPL) yra dažnai pasitaikanti liga, kurios galima išvengti ir kurią būtina gydyti. LOPL būdinga nuolatinè ir progresuojanti kvėpavimo takų obstrukcija, susijusi su stipresne kvejpavimo takų ir plaučių uždegimine reakcija ị ịkvepiamas žalingas daleles ar dujas. Svarbiausi LOPL rizikos veiksniai yra tabako rūkymas, aplinkos teršalai, genetinè predispozicija ir sunkios respiracinès infekcijos vaikystejje. Tyrimo tikslas - ịvertinti, susisteminti ir išanalizuoti mokslineje literatūroje pateikiamus duomenis apie lètinès obstrukcinès plaučių ligos reikšmingus rizikos veiksnius, galinčius turèti įtakos šios patologijos vystymuisi.
\end{abstract}

\section{Ivadas}

Lètinè obstrukcinè plaučių liga (LOPL) yra dažnai pasitaikanti liga, kurios galima išvengti ir kurią būtina gydyti. LOPL būdinga nuolatinè ir progresuojanti kvėpavimo takų obstrukcija, susijusi su stipresne kvėpavimo takų ir plaučių uždegimine reakcija ị ịkvepiamas žalingas daleles ar dujas. LOPL pirmiausia serga rūkaliai ir vyresni negu 40 metų žmonès. Paplitimas didejja, didejant amžiui. Šiuo metu LOPL yra trečia pagal dažnumą sergamumo ir mirtingumo priežastis visame pasaulyje [1]. Svarbiausi LOPL rizikos veiksniai yra tabako rūkymas, aplinkos teršalai, genetinè predispozicija ir sunkios respiracinès infekcijos vaikystëje. Cigarečių rūkymas yra labiausiai paplitusi LOPL priežastis visame pasaulyje, lemianti 80 proc. visų LOPL atvejų. Kitos priežastys gali būti pasyvusis rūkymas, aplinkos ir darbo aplinkoje esanti tarša bei alfa-1 antitripsino stoka [2]. Ši liga dažnai pasireiškia kosulio, dusulio ir skrepliavimo simptomais. Pacientų klinikinè ligos išraiška gali būti nuo besimptomès iki kvèpavimo nepakankamumo [1]. Svarbiausi LOPL gydymo principai yra metimas rūkyti, bronchų laidumo gerinimas, kvèpavimo takų uždegimo slopinimas, fizinio pajègumo gerinimas, kvèpa- vimo takų infekcijos ligai paūmèjus slopinimas [3].

Tyrimo tikslas - išanalizuoti bei aptarti ịrodymais pagrịstą informaciją apie lètinès obstrukcinès plaučių ligos rizikos veiksnius.

\section{Tyrimo medžiaga ir metodai}

Taikyta sisteminè mokslinès literatūros bei dokumentų apžvalga ir analizè. Duomenų buvo ieškoma Google Scholar, UpToDate, Cochrane bei Medline (PubMed) duomenu bazèse. Visateksčiai straipsniai atrinkti, jei jų pavadinimas, santrauka ar reikšminiai žodžiai nurodè, kad tyrimas tinkamas įtraukti ị šią apžvalgą. Pasirinktos tik anglų kalba skelbtos publika cijos. Vartoti nurodyti raktažodžiai. Atrinkti, išanalizuoti ir apibendrinti 7 straipsniai.

\section{Tyrimo rezultatai}

Rizikos veiksniai. Lètinė obstrukcinė plaučių liga (LOPL) yra sudètingos klinikinių ir molekulinių (t.y. genetinių) rizikos veiksnių sąveikos rezultatas. Šios sąveikos yra priežastis, dèl kurios du asmenys gali turèti vienodus klinikinius rizikos veiksnius, tačiau tik vienam iš jų išsivystys LOPL. Nustačius LOPL rizikos veiksnius ir geriau suprantant jų sąveiką, gali būti sukurtos geresnès strategijos, mažinančios LOPL paplitimą.

Nustatyti LOPL rizikos veiksniai yra rūkymas ir padidejjęs kvèpavimo takų jautrumas. Be rūkymo, reikšmingi aplinkos veiksniai, kurie gali būti atopija ir antioksidantų trūkumas [4]. Rūkymas yra kone reikšmingiausias ir labiausiai pasaulyje paplitęs LOPL rizikos veiksnys [1]. Kaip pavyzdys, atliktame retrospektyviniame kohortiniame tyrime nustatyta, kad tiriamieji, kurie rūkè cigaretes per 25 metų stebėjimo laikotarpị, dažniau nei nerūkantieji sirgo LOPL (susirgo 36\% rūkiusių ir 8\% nerūkiusių) [5]. Vienu metu rūkant tabako ir marihuanos gaminius, didèja LOPL atsiradimo rizika. Remiantis daugeliu stebejjimo tyrimų, padideję̧s kvejpavimo takų jautrumas ị aplinkoje esančius alergenus ar kitus išorinius veiksnius yra vienas iš LOPL rizikos veiksnių. Daugybė tyrimų rodo, kad kontaktas su aplinkoje esančiomis 
kietosiomis dalelèmis, dulkèmis, garais, dūmais ar organiniais antigenais taip pat gali būti LOPL rizikos veiksnys [6]. Moterys labiau linkusios sirgti LOPL. Rizika dideja, esant atopijai. Lengva arba vidutinio sunkumo astma taipogi yra LOPL išsivystymo rizikos veiksnys. Yra nedaug duomenų, rodančių, kad antioksidacinių vitaminų (pvz., vitaminų C ir E) trūkumas gali būti LOPL rizikos veiksnys. Teoriškai dèl antioksidacinių vitaminų trūkumo šeimininkas negali apsiginti nuo destruktyvaus oksidacinių radikalų poveikio, galinčio atsirasti iš egzogeninių šaltinių (pvz., cigarečių dūmų) bei endogeninių šaltinių (pvz., plaučiuose esančių fagocitų) [4].

Tyrimai rodo, kad egzistuoja LOPL molekuliniai rizikos veiksniai. Pavyzdžiui, vienas stebejjimo tyrimas parodè, kad LOPL rizika buvo maždaug tris kartus didesnè pacientams, kurių pirmos eilès giminaičiai sirgo sunkia LOPL, nesusijusia su alfa-1 antitripsino stoka [7]. Buvo nustatyti keli genų polimorfizmai, galintys padidinti LOPL riziką. Rasti genetiniai antioksidacinių fermentų funkcijos ar reguliavimo pokyčiai, turintys įtakos LOPL išsivystymui. Manoma, kad glutationo S-transferazių P1 ir M1, glutamato cisteino ligazės ir superoksido dismutazès genai yra labiausiai susiję. Daugelis stebejjimo tyrimų parodè ryšį tarp LOPL ir nenormalaus tam tikrų metaloproteinazių arba metaloproteinazių audinių inhibitorių potipių aktyvumo [4].

\section{Išvados}

1. Lètinè obstrukcinè plaučių liga atsiranda dèl sudètingos sąveikos tarp klinikinių ir molekulinių rizikos veiksnių.

2. Aiškūs arba galimi lètinès obstrukcinès plaučių ligos rizikos veiksniai yra aplinkoje esantys ir inhaliuojami teršalai (pvz., rūkymas), padidèjęs kvėpavimo takų jautrumas, atopija bei antioksidantų trūkumas.

3. Molekuliniai lètinès obstrukcinès plaučių ligos rizikos veiksniai yra įvairių genų polimorfizmai, su antioksidantais susiję fermentų funkcijos sutrikimai bei metaloproteinazių reguliacijos sutrikimai.

\section{Literatūra}

1. Agarwal AK, Raja A, Brown BD. Chronic obstructive pulmonary disease. StatPearls Publishing 2021.

2. Singh D, Agusti A, Anzueto A, Barnes PJ, Bourbeau J, Celli BR, et al. Global strategy for the diagnosis, management, and prevention of chronic obstructive lung disease: the GOLD science committee report 2019. Eur Respir J 2019;53(5).

https://doi.org/10.1183/13993003.00164-2019

3. Danila E., Sakalauskas R., Zablockis R., Malakauskas K., Bagdonas A., Biekšienė K. ir kt. Lètinès obstrukcinès plaučių ligos diagnostika ir gydymas. Vilnius, 2015:66.
4. Weiss ST. Chronic obstructive pulmonary disease: Risk factors and risk reduction. UpToDate 2021.

https://www.uptodate.com/contents/chronic-obstructivepulmonary-disease-risk-factors-and-risk-reduction

5. Zheng T, Zhu Z, Wang Z, et al. Medline ${ }^{\circledR}$ Abstract for Reference 9 of 'Chronic obstructive pulmonary disease: Risk factors and risk reduction'. J Clin Invest. 2000;106(9):1081.

https://doi.org/10.1172/JCI10458

6. Wang C, Xu J, Yang L, Xu Y, Zhang X, Bai C, et al. Prevalence and risk factors of chronic obstructive pulmonary disease in China (the China Pulmonary Health $[\mathrm{CPH}]$ study): a national cross-sectional study. Lancet 2018;391(10131):1706-17. https://doi.org/10.1016/S0140-6736(18)30841-9

7. Silverman EK, Chapman HA, Drazen JM, Weiss ST, Rosner B, Campbell EJ, et al. Genetic epidemiology of severe, early-onset chronic obstructive pulmonary disease. Risk to relatives for airflow obstruction and chronic bronchitis. Am J Respir Crit Care Med 1998;157(6 Pt 1):1770-8.

https://doi.org/10.1164/ajrccm.157.6.9706014

\section{CHRONIC OBSTRUCTIVE LUNG DISEASE (COPD): RISK FACTORS \\ A. Naujokaitytè}

Keywords: chronic obstructive pulmonary disease, COPD, risk factors.

Summary. Chronic obstructive pulmonary disease (COPD) is a common disease that can be prevented and treated. COPD is characterized by persistent and progressive airway obstruction associated with a stronger inflammatory response of the airways and lungs to inhaled harmful particles or gases. The most important risk factors for COPD are tobacco smoking, environmental pollutants, genetic predisposition, and severe childhood respiratory infections. The aim of this study was to evaluate, systematize and analyze the data presented in the scientific literature on chronic obstructive pulmonary disease, what significant risk factors may influence the development of this pathology.

Conclusions: 1. Chronic obstructive pulmonary disease results from a complex interaction between clinical and molecular risk factors. 2. Clear or potential risk factors for chronic obstructive pulmonary disease include environmental and inhaled pollutants (eg, smoking), respiratory sensitivity, atopy, and antioxidant deficiency. 3. Molecular risk factors for chronic obstructive pulmonary disease include polymorphisms in various genes, antioxidant-related enzyme dysfunction, and dysregulation of metalloproteinases.

Correspondence to: aiste.naujokaityte@mf.stud.vu.lt

Gauta 2021-04-22 